\title{
INFLUENCE OF PALM OIL BIOMASS CLINKER AND EMPTY FRUIT BUNCH FIBERS ON CONCRETE PROPERTIES
}

\author{
MOHD HAZIMAN WAN IBRAHIM ${ }^{*}$, SAJJAD Ali MANGI ${ }^{2}$, \\ ShaRIFAHSAlWA MOHD ZUKI ${ }^{1}$, RAMAdHANSYAH PUTRA JAYA ${ }^{3}$, \\ DADANG SUPRIYATNO ${ }^{4}$ \\ ${ }^{1}$ Jamilus Research Center, Faculty of Civil Engineering and Built Environment, \\ Universiti Tun Hussein Onn Malaysia, 86400, Parit Raja, Johor, Malaysia. \\ ${ }^{2}$ Department of Civil Engineering, Mehran University of Engineering and Technology, \\ SZAB Campus Khairpur Mir's, Sindh, Pakistan. \\ ${ }^{3}$ Department of Civil Engineering, College of Engineering, \\ Universiti Malaysia Pahang, 26300, Kuantan, Pahang, Malaysia. \\ ${ }^{4}$ Faculty of Engineering, Universitas Negeri Surabaya, Indonesia. \\ "Corresponding author: haziman@uthm.edu.my
}

(Received: $3^{\text {rd }}$ November 2019; Accepted: $22^{\text {nd }}$ March 2020; Published on-line: $4^{\text {th }}$ July 2020)

\begin{abstract}
This study aims to evaluate the influence of palm oil Empty Fruit Bunch (EFB) fibers on flexural strength performance of concrete in the presence of Palm Oil Biomass Clinker (POBC). This study considered various proportions of palm oil EFB fibers as $0 \%, 0.2 \%, 0.4 \%$, and $0.6 \%$ in concrete with fixed amount of POBC as $10 \%$. It was investigated that there is substantial influence of palm oil EFB fibers on properties of concrete containing $10 \%$ POBC as sand replacement. The experimental findings of this study indicated that the workability of fresh mix concrete decreases as palm oil EFB fiber content increased. Besides that, hardened properties of concrete were found to be improved as the amount of palm oil EFB fibers increased in the concrete. It was noticed that flexural strength was improved with addition of $0.2 \%$ palm oil EFB fibers that act as reinforcement and deliver growth in flexural strength for concrete containing $10 \%$ of POBC. Hence, it was concluded that palm oil EFB fiber could be utilized as fiber reinforcement in concrete to improve flexural strength performance of the concrete.
\end{abstract}

ABSTRAK: Kajian ini bertujuan mengkaji pengaruh gentian tandan kelapa sawit (EFB) terhadap kekuatan lentur pada konkrit dengan kehadiran klinker minyak kelapa sawit biomas (POBC). Kajian ini mengguna pakai pelbagai peratus serat EFB kelapa sawit dalam konkrit iaitu sebanyak $0 \%, 0.2 \%, 0.4 \%$, dan $0.6 \%$ dengan jumlah tetap POBC sebanyak $10 \%$. Didapati bahawa gentian tandan kelapa sawit EFB yang mengandungi $10 \%$ POBC berpengaruh besar sebagai pengganti pasir dalam bahan konkrit. Penemuan eksperimen menunjukkan bahawa kebolehkerjaan campuran baru konkrit berkurangan apabila kandungan gentian EFB minyak sawit meningkat. Selain itu, sifat-sifat mengeras pada konkrit didapati bertambah baik apabila jumlah gentian EFB minyak sawit meningkat dalam konkrit. Di samping itu, kekuatan lenturan meningkat dengan penambahan sebanyak $0.2 \%$ serat EFB minyak kelapa sawit, berfungsi sebagai penguat dan penambah kekuatan lenturan pada konkrit yang mengandung 10\% POBC. Oleh itu, serat EFB minyak kelapa sawit boleh digunakan sebagai penguat gentian dalam konkrit bagi meningkatkan kekuatan lenturan konkrit.

KEYWORDS: bunch fiber; biomass clinker; compressive strength; flexural strength 


\section{INTRODUCTION}

The production of palm oil has been increased over the years. According to a recent report by the Malaysia Palm Oil Board (MPOB), crude palm oil production has increased from 24.91 to 28.64 million tons in a year [1]. This huge quantity of palm oil production left behind the waste by-products known as Palm Oil Biomass Clinker (POBC) and palm oil Empty Fruit Bunch (EFB). In Malaysia, EFB is being utilized as a fertilizer for the agricultural field and $\mathrm{POBC}$ is being considered in concrete as cement and sand replacement material. $\mathrm{POBC}$ is a waste material produced through incineration of oil palm shells and mesocarp fiber as fuel for stream turbines in mills [2]. A massive quantity of POBC is usually dumped into landfills, which causes environmental problems. How ever, use of sustainable materials should be given immediate attention and emphasis on the sustainable development through adopting waste by-products into the potential construction material [3].

The POBC has a lower value of specific gravity and higher crushing value, which indicates its potentiality to be considered as an alternative source of fine aggregate. There is no pre-treatment or modification required for this material. The adoption of POBC as fine aggregate to some extent could save the depletion of natural resources [2]. Recent study was conducted by Wan Ibrahim et al. [4] on POBC as fine aggregate replacement in concrete with hooked-end steel fibers. They considered a 10\% proportion of POBC to be an optimum replacement level of fine aggregates in concrete. However, this method can reduce the self-weight of concrete, which delivers lightweight and green and su stain able concrete. Beside that palm oil EFB fiber is one of the local natural fibers, which can easily be obtained at low cost and low level of energy either in manpower or technology. Hence, this study aims to investigate the influence of palm oil EFB fiber on the fresh and hardened concrete properties with $10 \%$ POBC as fine aggregate.

\section{PREVIOUS RELATED RESEARCH}

\subsection{Effects of POBC on Concrete Properties}

Concrete containing POBC as fine aggregate is influenced by the physical properties of POBA. However, POBC is a porous material that absorbs more water than normal aggregates, its water absorption was noted in the range of 4.7-26.5\%, which deliver low workability concrete [5]. It was also declared by Ahmmad, et al. [6] that lightweight concrete can integrate more waste materials like crushed Oil Palm Shell (OPS) as coarse aggregate and Palm Oil Clinker (POC) as a replacement of fine aggregate. They declared that the modulus of elasticity was $23 \%$ higher in OPS concrete. The lower compressive strength of self-compacting concrete was observed when fully or partially coarse and fine aggregate were replaced with POC [2].

Gunasekaran et al. [7] considered Coconut Shell Concrete (CSC). They declared that workability and tensile and flexural strength were improved. Overall, CSC bond strength is comparable to that of normal and lightweight aggregate concretes. However, they further declared that coconut shells fulfil the provisions to be used as aggregate for lightweight concrete.

Abutaha et al. [8] investigated the compressive strength of concrete with Palm Oil Clinker (POC) as coarse and fine aggregate. They declared that the amount of POC in the mix reduces the compressive strength of the concrete as shown in Fig. 1, which shows that the targeted compressive strength of Grade 40 concrete was achievable with $10 \%$ coarse aggregate replacement with POC. The strength declined by $11.73 \%, 16.79 \%, 18.94 \%$, 
$19.66 \%, 21.60 \%$ and $30.37 \%$ at the replacement levels of $10 \%, 20 \%, 40 \%, 60 \%, 80 \%$ and $100 \%$ respectively. The maximum drop of strength was noticed with full replacement of coarse aggregate. Nevertheless, the compressive strength performance of concrete with POC as fine aggregate is far better than coarse aggregate replacement. It was observed that POC as fine aggregate can enhance the compressive strength as shown in Fig. 2. It indicated that at the replacement level of $10 \%, 20 \%, 40 \%, 60 \%$ and $100 \%$ the compressive strength was noticed as decreased by $4.07 \%, 4.43 \%, 0.15 \%, 0.80 \%$, and $5.17 \%$, respectively. However, compressive strength was found to be 5\% improved at $80 \%$ replacement. These results show the potentiality of POC to be utilized as replacement of fine aggregate. Therefore, this study also considered the $10 \%$ replacement.

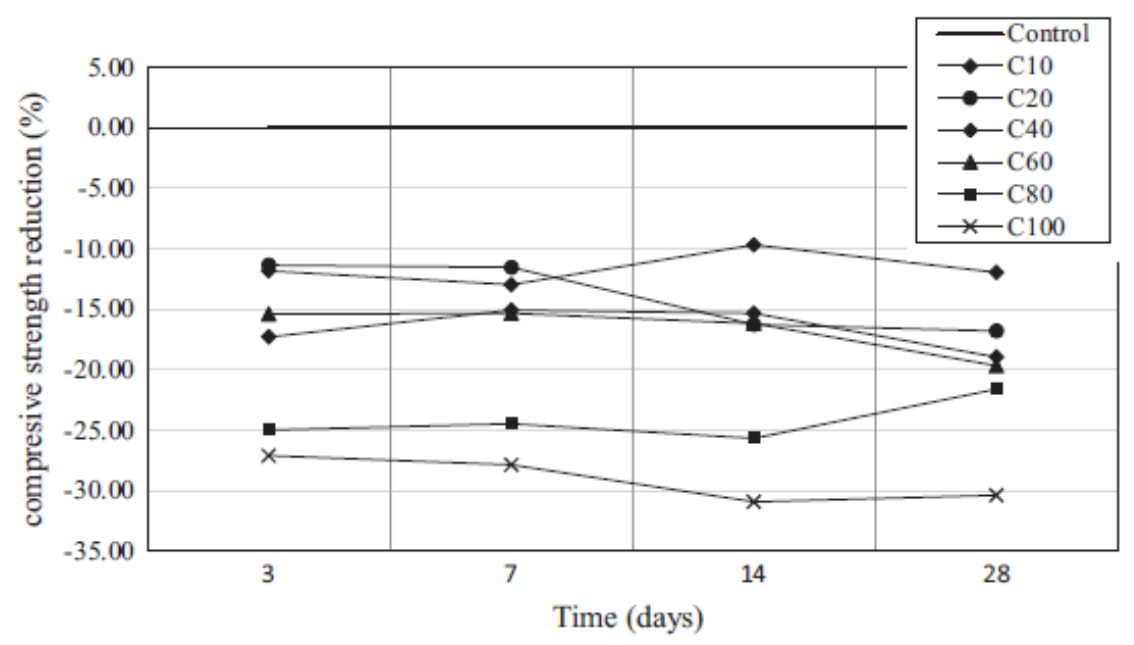

Fig. 1: Concrete strength performance with POC as replacement of coarse aggregates [8].

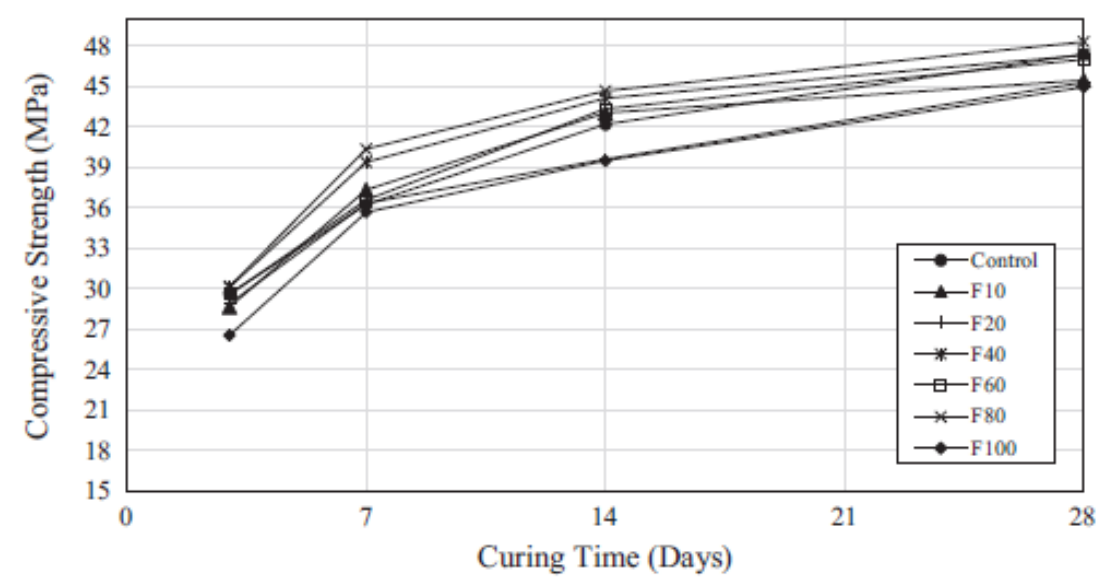

Fig. 2: Concrete strength performance with POC as replacement of fine aggregates [8].

Furthermore, Shahreen et al. [9] examined the flexural strength of concrete comprising POC as fine aggregate replacement. It showed a positive increment in flexural strength at early ages due to the presence of POC fine particles, which creates a pozzolanic reaction and densification of the concrete mix and enhanced internal bonds among aggregates and cement paste, resulting in the development of strength as seen in the results provided in Fig. 3. They declared that fine particles of POC occup y the free spaces in the 
concrete and fill the voids, which delivers high density and increases the stability of the concrete mix. It was noticed that the flexural strength of concrete was increased around $28 \%$ and $33 \%$ with incorporation of $5 \%$ and $10 \%$ of POBC as fine aggregates, respectively [9]. However, the opposite results were found with more than $10 \%$ of POBC [10]. The adverse influence was noticed with the utilization of $\mathrm{POBC}$ as coarse and fine aggregate $\mathrm{s}$ in concrete.

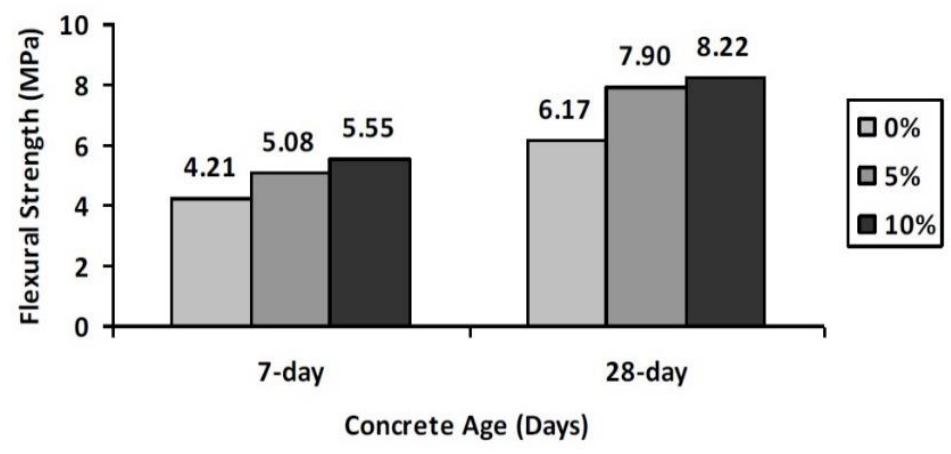

Fig. 3: Flexural strength result of POC concrete and conventional concrete [9].

From the literature review it can be concluded that the presence of POBC can affect the performance of concrete. Therefore, the flexural strength performance would be improved with the addition of fiber along with the $10 \%$ proportion of $\mathrm{POBC}$ as fine aggregate replacement.

\subsection{Effects of Natural Fiber to Concrete}

Particularly in tropical states like Malaysia and Indonesia, palm oil EFB are the abundant waste that is left behind after the fruits are stripped from fruit bunches for the oil extraction process [11]. EFB fiber is a type of fiber that is clean and free from pesticides. This fiber could be utilized in concrete to improve its performance. It was previously well known that the inclusion of fibers in concrete creates reinforced concrete that delivers better strength than normal concrete. For instance, previous research work has been summarized below on the fiber proportion and performance of concrete.

Sim et al. [12] investigated the influence of basalt fiber on structural concrete and found that basalt fiber is a good substitute for strengthening concrete structures. In addition, Kim et al. [13] considered two type of concretes; normal concrete and highfluidity concrete. Whereas, they found that the addition of $1 \%$ jute fiber by volume in the normal strength concrete does not deliver significant increment, but in high-fluidity concrete it gives a substantial rise in compressive strength, around $55 \%$, as compared to one without fiber. The compressive strength of $0 \%$ jute fiber content for high-fluidity concrete gives $25 \mathrm{MPa}$ and for $0.5 \%$ of jute fiber content deliver about $42 \mathrm{MPa}$, which indicated that the presence of fibers could positively influence the concrete performance. Hence, it was generally observed that the flexural strength can be increased as the fiber content increased in concrete. However, presence of fiber can resist tensile load and increase the flexural strength. 


\section{MATERIALS AND METHODOLOGY}

\subsection{Materials}

Ordinary Portland cement (OPC) was used in this study. The coarse aggregates were collected from Muar, Johor, Malaysia. This study considered a $10 \mathrm{~mm}$ average of coarse aggregate. After collection, coarse aggregates were dried under open sun for few days to achieve saturated surface dry (SSD) conditions. However, the fine aggregates (sand) were transported from a river in Kahang, Johor, Malaysia. The fine aggregates were also dried for a few days under open sunlight to achieve saturated surface dry (SSD) conditions. Before mixing, the sand was sieved through a $5 \mathrm{~mm}$ sieve.

\subsection{Palm Oil Biomass Clinker}

This study considered Palm Oil Biomass Clinker (POBC) as shown in Fig. 4, which was collected from a biomass steam plant located in Tanjung Langsat, managed by TPM Technopark Sdn Bhd. Initially, it was partially replaced by the fine aggregate (sand). The optimum replacement percentages of sand with $\mathrm{POBC}$ was chosen as $10 \%$ based previous studies [4]. Afterward, POBC were passed through a $5 \mathrm{~mm}$ sieve size. Furthermore, a random sample of POBC was investigated with a Scanning Electron Microscope (SEM) for an understanding of its microstructure, as shown in Fig. 5. It was observed that POBC has micro voids that could affect the properties of concrete and create weak region s in the form of free voids. The presence of voids is the significant cause of reduction in strength of concrete. These voids also provide a gap between particles and result in weaker bond $\mathrm{s}$ in the hardened concrete. Some organic compounds were noticed on the surface of the POBC. It can be concluded that POBC contains voids and organic compounds that affect its porosity and low value of specific gravity.

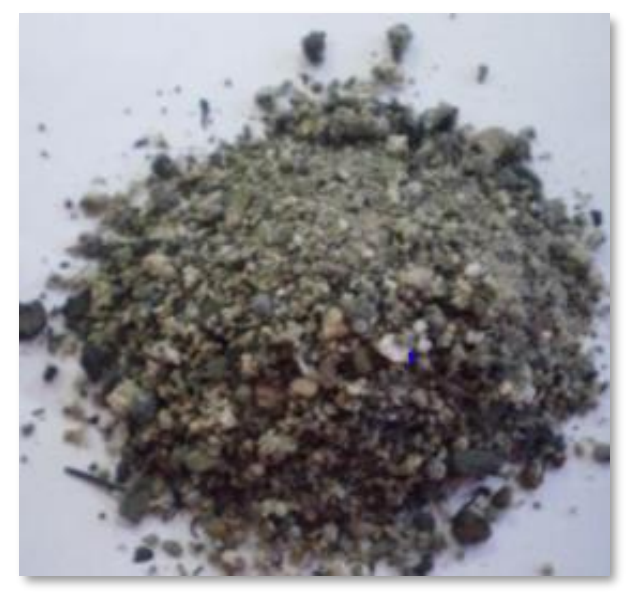

Fig. 4: Palm oil biomass clinker.

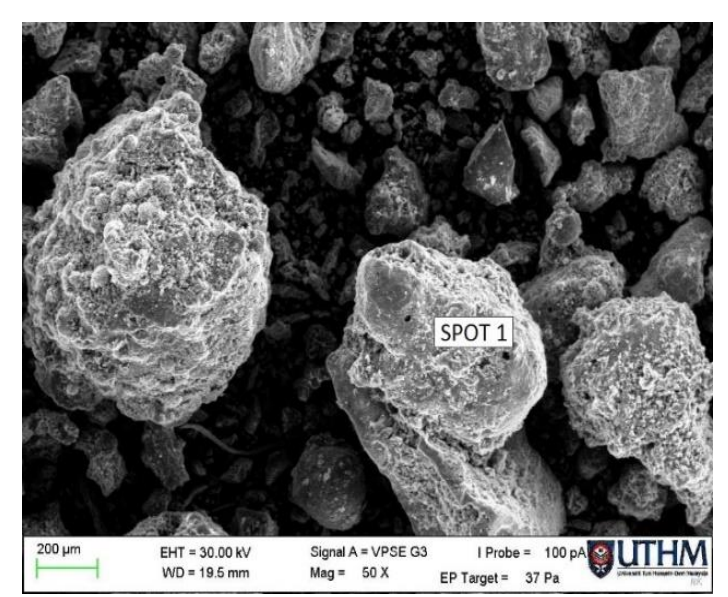

Fig. 5: SEM image of POBC.

\subsection{Palm Oil Empty Fruit Fibers}

Palm oil empty fruit bunch (EFB) fibers, as shown in Fig. 6, were used in this study. The length of the palm oil EFB fiber was fixed at the range of $30 \mathrm{~mm}$ to $50 \mathrm{~mm}$ with a diameter of around $0.05 \mathrm{~mm}$. The aspect ratio of the palm oil EFB fibers was in the range of 60 to 100 for better strength development. 


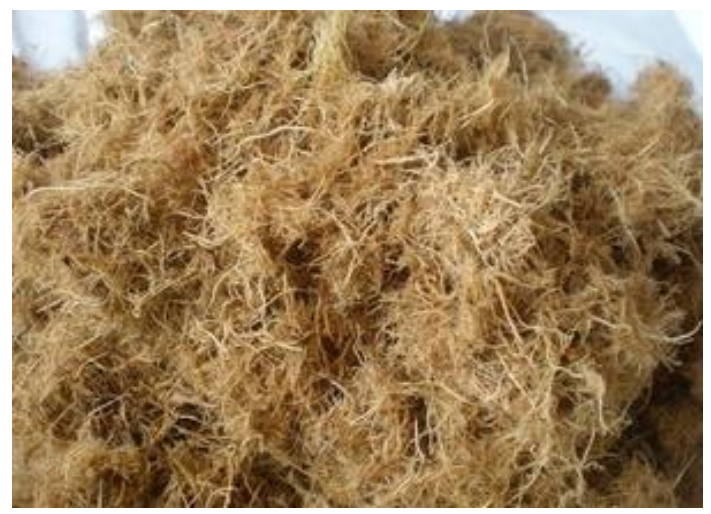

Fig. 6: Palm oil empty fruit bunch fibers.

\subsection{Experimental Procedure}

In this study, normal concrete mix design was prepared for $25 \mathrm{MPa}$ at 28 days with a fixed water-to-cement ratio of 0.50. A total of four mixes were prepared; one was the reference mix with $10 \%$ POBC but without fibers and the other three contained varying amounts of palm oil EFB fiber at $0.2,0.4$ and $0.6 \%$ by weight total batch mix. The quantity of fiber was calculated by multiplying the overall weight of ingredients of the concrete mix with the percentage of fiber content. The concrete mix details are provided in Table 1.

Table 1: Mix design detail $\left(\mathrm{kg} / \mathrm{m}^{3}\right)$ for concrete containing POBC with palm oil EFB fiber

\begin{tabular}{ccccccc}
\hline $\begin{array}{c}\text { Sample } \\
\text { Notation }\end{array}$ & Cement & Sand & CA & POBC & Water & $\begin{array}{c}\text { EFB } \\
\text { Fibers }\end{array}$ \\
\hline $0 \%$ EFB & 18.24 & 37.80 & 28.62 & 0.00 & 9.12 & - \\
$0.2 \%$ EFB & 18.24 & 34.02 & 28.62 & 3.78 & 9.12 & 0.195 \\
$0.4 \%$ EFB & 18.24 & 34.02 & 28.62 & 3.78 & 9.12 & 0.390 \\
$0.6 \%$ EFB & 18.24 & 34.02 & 28.62 & 3.78 & 9.12 & 0.585 \\
\hline
\end{tabular}

Overall, 48 specimens were prepared to explore the compressive and flexural strength of the concretes at 7 and 28 days, as mentioned in Table 2. Concrete cubes of $100 \mathrm{~mm}$ size were cast for the purpose of compressive strength. The prisms of $100 \mathrm{~mm}$ in cross-section and $500 \mathrm{~mm}$ in length were cast for the evaluation of flexural strength. Furthermore, curing of concrete was observed under water immersion conditions.

Table 2: The Specimen prepared for strength performances

\begin{tabular}{|c|c|c|c|c|}
\hline \multirow{2}{*}{$\begin{array}{l}\text { Palm Oil EFB } \\
\text { fibers }(\%)\end{array}$} & \multicolumn{2}{|c|}{7 days } & \multicolumn{2}{|c|}{28 days } \\
\hline & Compressive & Flexural & Compressive & Flexural \\
\hline 0 & 3 & 3 & 3 & 3 \\
\hline 0.2 & 3 & 3 & 3 & 3 \\
\hline 0.4 & 3 & 3 & 3 & 3 \\
\hline 0.6 & 3 & 3 & 3 & 3 \\
\hline Sub Total & 12 & 12 & 12 & 12 \\
\hline Tota1Samples & & & & \\
\hline
\end{tabular}




\section{RESULTS AND DISCUSSION}

\subsection{Particle Size Distribution}

Particle size distribution has been done through sieve analysis. Fig. 7 illustrates the cumulative percentages passing for sand and POBC at various sieve sizes. However, the sand and POBC particle size distribution curve did not exceed the upper and lower limits. Both sand and POBC used in the experiment fulfil the particle size behaviour stated in BS 882: 1992, the required percentage by mass passing BS sieve for sand. In this study, aggregates used were air dried to obtain saturated dried surface. To achieve this condition, aggregates were dried at room temperature for 24 hours.

Coarse aggregates of $10 \mathrm{~mm}$ size were used, and less than $5 \mathrm{~mm}$ were removed through sieving. The specific gravity for sand and POBC used in this study has the average specific gravity of 2.07 and 2.63 , respectively. The specific gravity of POBC is $21 \%$ lower than the average specific gravity of sand.

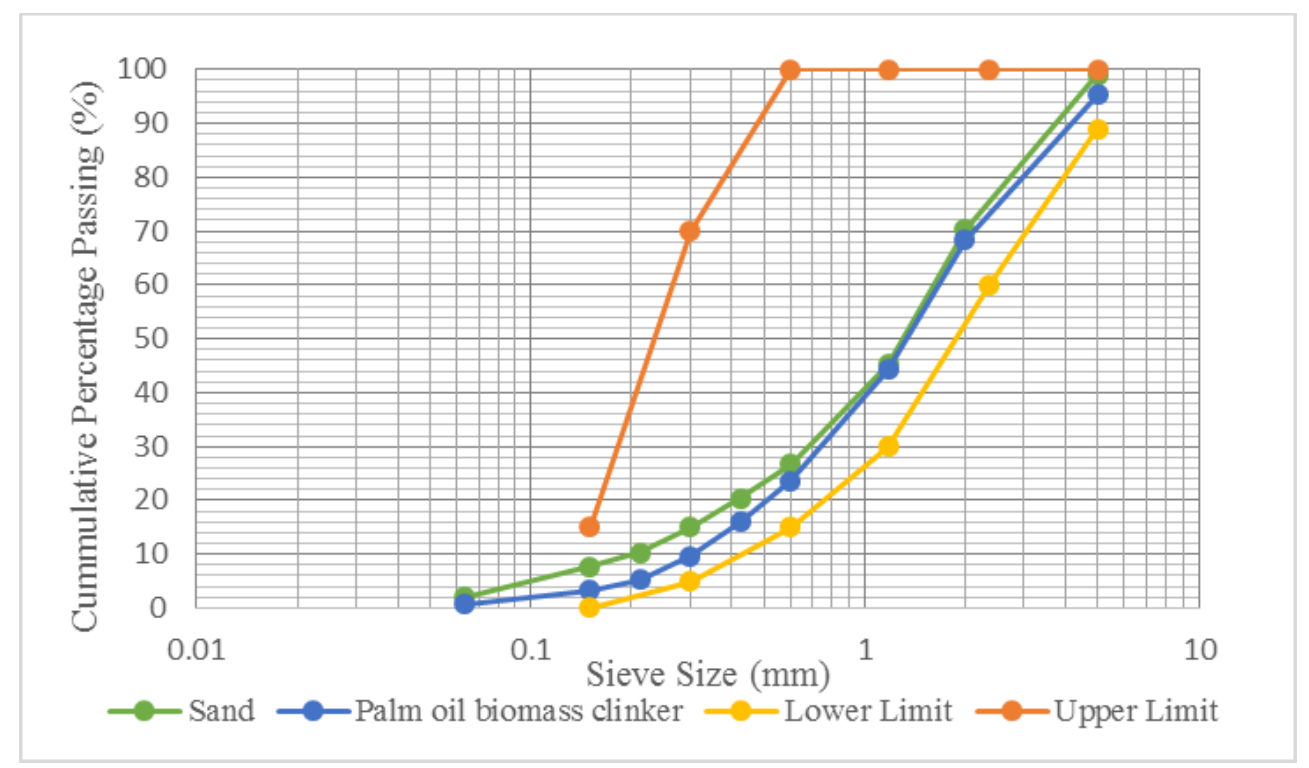

Fig. 7: Particle size distribution of sand and POBC.

\subsection{Workability of Concrete}

Workability is an aspect of concrete, which indicates flow without mechanical shaking. The workability performance of concrete containing 10\% POBC along with various proportions of palm oil EFB fiber are presented Fig. 8. It shows a reduction in workability due to the addition of fiber content. The slump value dropped from $20 \mathrm{~mm}$ to 18,12 , and $8 \mathrm{~mm}$ at fiber contents of $0.2,0.4$, and $0.6 \%$, respectively. The results showed a substantial decrease in workability due to presence of fiber. As the fiber content increased, workability was reduced. However, the presence of fiber absorbed more water in the concrete mix [14] and resulted in the drop in workability. An adequate performance was noticed with $0.2 \%$ fiber. It was also previously noticed by Ahmad et al. [15] that the addition of fibers cause the reduction in workability. However, the palm oil EFB fiber is an organic fiber that could reduce the quantity of free water in a concrete mixture and affect the mobility of concrete. 


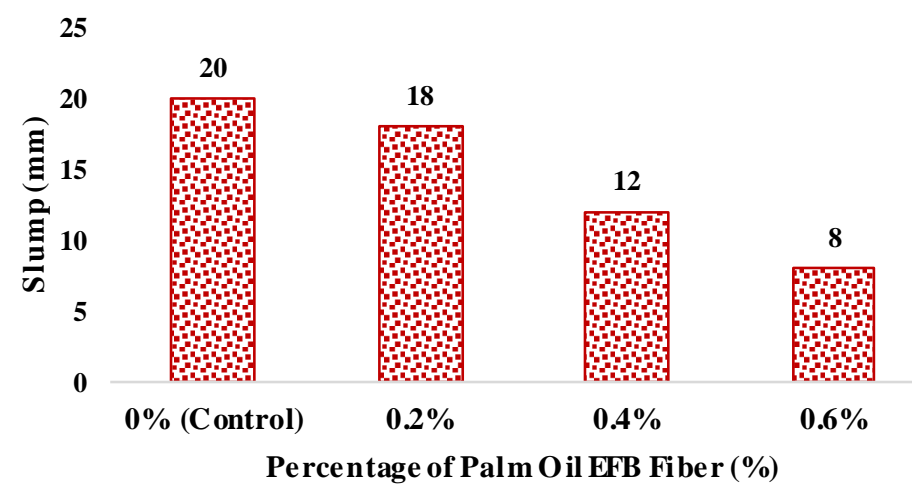

Fig. 8: The slump value with various percentage of reinforced palm oil EFB fiber.

\subsection{Compressive Strength}

Compression strength test performances of concrete with $10 \% \mathrm{POBC}$ as a fine aggregate replacement with the addition of $0.2 \%, 0.4 \%$, and $0.6 \%$ of palm oil EFB fiber has been presented in Fig. 9. The experimental findings indicate that compressive strength was reduced as fiber quantity increased in the concrete. The control sample with out fiber shows the highest compressive strength of $27.23 \mathrm{MPa}$ at 28 days. Compressive strength results with the addition of $0.2 \%, 0.4 \%$ and $0.6 \%$ palm oil EFB fiber show a reduction in strength of $12.6 \%, 17.7 \%$, and $21.7 \%$ respectively. Comparatively, the strength performances with $0.2 \%$ fiber is considered to be satisfactory, due to the lower reduction in the strength $[4,16,17]$. This study clarifies that there is a continual decrease in compressive strength as palm oil EFB fibers increase in the concrete mix. It shows that concrete becomes more porous and delivers lower strength. This study also validated that in the presence of both materials, POBC and palm oil EFB fiber, concrete depletes its water content, since more water is absorbed by these two materials. As a result, reduction in water content could slow the hydration process of concrete and ultimately cause it to exhibit lower strength, even at 28 days.

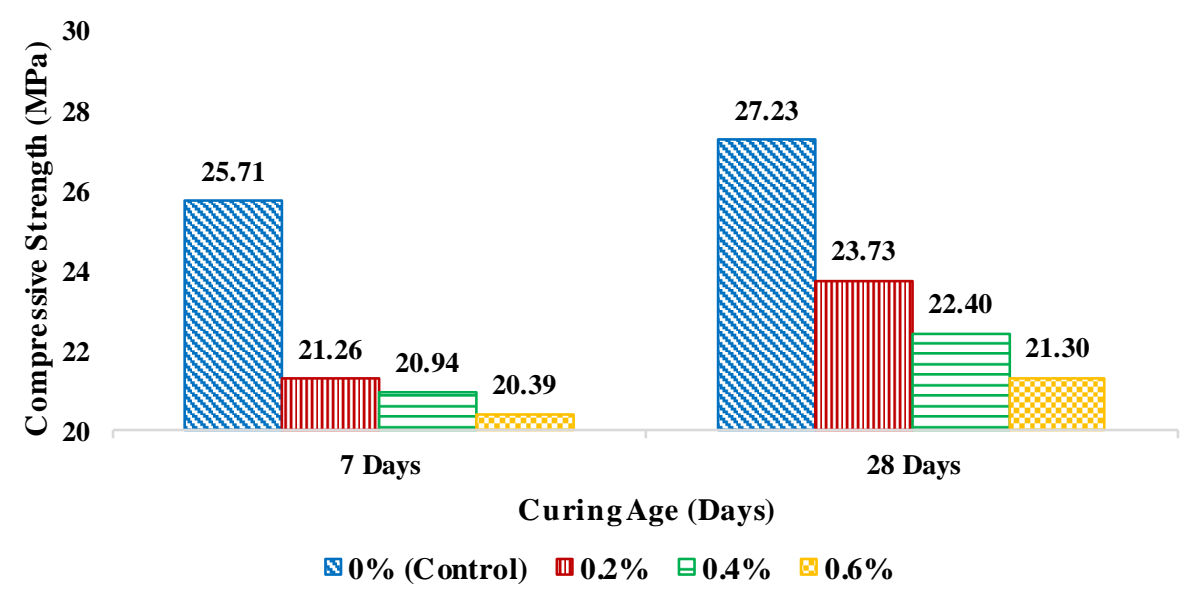

Fig. 9: Compressive strength of fiber reinforced concrete at different curing periods

\subsection{Flexural Strength}

Experimental results of flexural strength of concrete incorporating $10 \% \mathrm{POBC}$ as fine aggregate replacement along with the addition of $0.2 \%, 0.4 \%$ and $0.6 \%$ of palm oil EFB 
fiber has been demonstrated in Fig. 10. It was observed that flexural strength of concrete was better in the presence of fibers. It was noticed that flexural strength was increased from 2.18 MPa to $2.43 \mathrm{MPa}$ with the addition of $0.2 \%$ fiber, which is almost $11.47 \%$ rise in flexural strength at 28 days. However, $0.4 \%$ and $0.6 \%$ fiber content also delivers around $5.96 \%$ and $4.59 \%$ improvement in the flexural strength of concrete. Hence, it is worth noting here that the increase in palm oil EFB fiber content causes a reduction in flexural strength. It was previously acknowledged that the addition of supplementary materials along with fibers enhances the flexural strength of concrete $[4,18,19,20,21]$. This study also experimentally validated that $0.2 \%$ proportion of fiber enhances the concrete properties in terms of flexural strength, and it is hereby recommended as an appropriate proportion of fibers in a concrete mix.

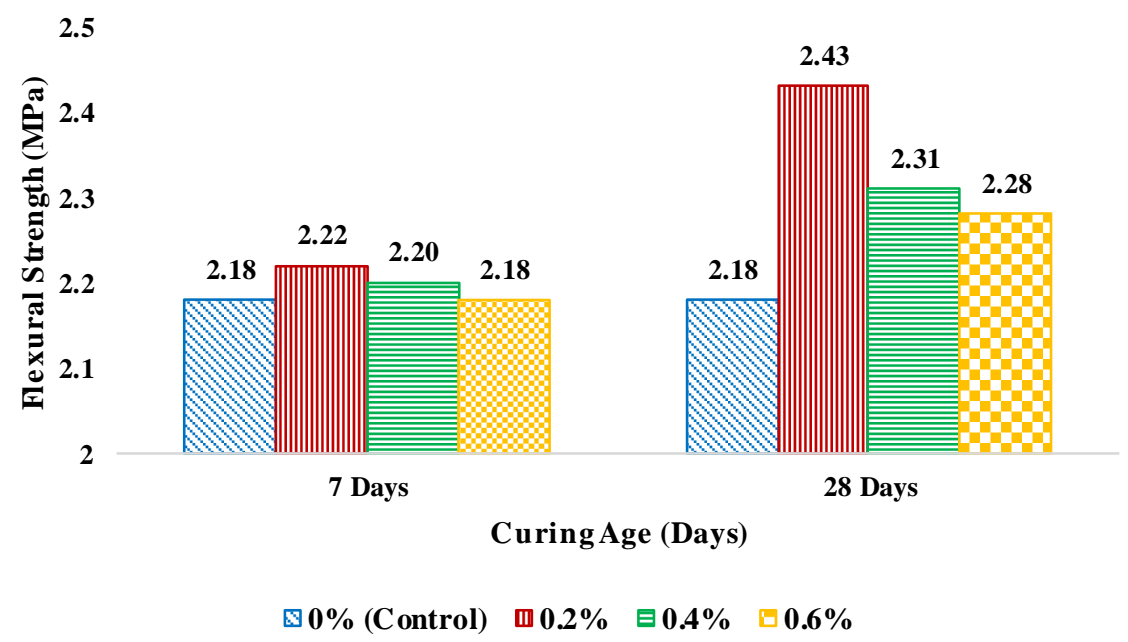

Fig. 10: Concrete flexural strength at curing periods of 7 and 28 days.

\section{CONCLUSIONS}

This experimental study confirmed that $\mathrm{POBC}$ has a good potential to be utilized as a fine aggregate replacement. Based on the performance of concrete containing $10 \%$ POBC as fine aggregate with addition of palm oil EFB fiber, the following conclusions can be made:

- Concrete containing $10 \%$ POBC as a fine aggregate along with addition of palm oil EFB fiber delivers lower workability performances and around $10 \%$ reduction in workability with the addition of $0.2 \%$ fiber in concrete.

- Concrete compressive strength was also reduced with addition of $0.2 \%, 0.4 \%$ and $0.6 \%$ palm oil EFB fiber, which gives around $12.6 \%, 17.7 \%$, and $21.7 \%$ reduction in compressive strength, respectively. However, $0.2 \%$ fiber content is declared as optimum, due to minimum reduction in the strength.

- The flexural strength performances of concrete were found to be increased from $2.18 \mathrm{MPa}$ to $2.43 \mathrm{MPa}$ with the addition of $0.2 \%$ fiber, which is almost an $11.47 \%$ rise in flexural strength at 28 days. Therefore, based on the experimental outcomes, the appropriate proportion of fiber is recommended to be $0.2 \%$. 


\section{ACKNOWLEDGEMENTS}

This study was supported by Universiti Tun Hussein Onn Malaysia (UTHM) and Ministry of Education Malaysia through Fundamental Research Grant Scheme Vot No. FRGS/1/2018/TK01/UTHM/02/3.

\section{REFERENCES}

[1] Kushairi A, Loh SK, Azman I, Hishamuddin E, Abdullah MO, Mohd Noor Izuddin ZB, Razmah G, Sundram S, Ahmad Parveez MK. (2018) Oil Palm Economic Performance in Malaysia and R\&D Progress in 2017 - Review Article. Journal of oil palm research 30(2):163-195. DOI: https://doi.org/10.21894/jopr.2018.0030

[2] Kanadasan J, Razak HA. (2015) Engineering and sustainability performance of selfcompacting palm oil mill incinerated waste concrete, J. Clean. Prod., 89:78-86. https://doi.org/10.1016/j.jclepro.2014.11.002

[3] Alengaram UJ, Al Muhit BA, Jumaat MZB. (2013) Utilization of oil palm kernel shell as lightweight aggregate in concrete - A review, Constr. Build. Mater., 38:161-172. https://doi.org/10.1016/j.conbuildmat.2012.08.026

[4] Wan Ibrahim, MH, Mangi SA, Ridzuan MB, Burhanudin MK, Jamaluddin N, Li KH., Shahidan S, Sheikh KF, Arshad MF, Ramadhansyah PJ. (2019) Compressive and Flexural Strength of Concrete Containing Palm Oil Biomass Clinker with Hooked-End Steel Fibers, Int. J. Integr. Eng., vol. 10(9):152-157. https://publisher.uthm.edu.my/ojs/index.php/ijie/article/view/2559

[5] Aslam M, Shafigh P, Jumaat MZ. (2016) Oil-palm by-products as lightweight aggregate in concrete mixture: A review, Journal of Cleaner Production, 126:56-73. https://doi.org/10.1016/j.jclepro.2016.03.100

[6] Ahmmad R, Jumaat MZ, Bahri S, Saiful Islam ABM. (2014) Ductility performance of lightweight concrete element containing massive palm shell clinker, Constr. Build. Mater., 63:234-241. https://doi.org/10.1016/j.conbuildmat.2014.04.022

[7] Gunasekaran K, Kumar PS, Lakshmipathy M. (2011) Mechanical and bond properties of coconut shell concrete, Constr. Build. Mater., 2:592-98. https://doi:10.1016/j.conbuildmat.2010.06.053

[8] Abutaha F, Razak HA, Kanadasan J. (2016) Effect of palm oil clinker (POC) aggregates on fresh and hardened properties of concrete, Constr. Build. Mater., 112:416-423. https://doi.org/10.1016/j.conbuildmat.2016.02.172

[9] Shahreen E, Wahab A, Omar R, Che Osmi SF, Muhamad Khairussaleh NA, Abdullah A. (2012) Preliminary study on Mechanical Properties of Concrete added with Fine Palm Oil Clinker, in Jordan Engineers Association Conferences. http://www.jeaconf.org

[10] Shafigh P, Mahmud HB, Jumaat MZB, Ahmmad R, Bahri S. (2014) Structural lightweight aggregate concrete using two types of waste from the palm oil industry as aggregate, J. Clean. Prod., 80. 187-196. https://doi.org/10.1016/j.jclepro.2014.05.051

[11] Gunawan FE, Homma H, Brodjonegoro SS, Hudin ABB, Zainuddin AB.(2009) Mechanical Properties of Oil Palm Empty Fruit Bunch Fiber, J. Solid Mech. Mater. Eng., 3(7):943-951. https://doi.org/10.1299/jmmp.3.943

[12] Sim J, Park C, Moon DY. (2005) Characteristics of basalt fiber as a strengthening material for concrete structures, Compos. Part B: Eng., 36(6-7):504-512. https://doi.org/10.1016/j.compositesb.2005.02.002

[13] Kim J, Park C, Choi Y, Lee H, Song G. (2012) An Investigation of Mechanical Properties of Jute Fiber-Reinforced Concrete. In: Parra-Montesinos G.J., Reinhardt H.W., Naaman A.E. (eds) High Performance Fiber Reinforced Cement Composites 6. RILEM State of the Art Reports, vol 2. Springer, Dordrecht. https://doi.org/10.1007/978-94-007-2436-5_10

[14] Shreeshail BH. (2015) Effects of Coconut Fibers on The Properties of Concrete, Int. J. Res. Eng. Technol., 04(01):5-11. 
[15] Ahmad Z, Saman HM, Tahir PM. (2010) Oil palm trunk fiber as a bio-waste resource for concrete reinforcement, Int. J. Mech. Mater. Eng., 5(2):199-207

[16] Mangi SA, Wan Ibrahim MH, Jamaluddin N, Arshad MF, Memon FA, Ramadhansyah PJ, Shahidan S. (2019) A Review on Potential Use of Coal Bottom Ash as a Supplementary Cementing Material in Sustainable Concrete Construction, Int. J. Integr. Eng., 10(9):127135. https://publisher.uthm.edu.my/ojs/index.php/ijie/article/view/2496

[17] Mangi SA, Wan Ibrahim MH, Jamaluddin N, Arshad MF, Ramadhansyah PJ. (2018) Effects of Ground Coal Bottom Ash on the Properties of Concrete, J. Eng. Sci. Technol. 14 (1):338350 . http://jestec.taylors.edu.my/Vol\%2014\%20issue\%201\%20February\%202019/14_1_24.pdf

[18] Dullah H, Akasah ZA, Nik Soh NMZ, Mangi SA. (2017) Compatibility improvement method of empty fruit bunch fibre as a replacement material in cement bonded boards: A review, IOP Conf. Ser. Mater. Sci. Eng., 271: 1-7. https://iopscience.iop.org/article/10.1088/1757-899X/271/1/012076

[19] Jamaluddin N, Hamzah AF, Wan Ibrahim MH, Ramadhansyah PJ, Arshad MF, Zainal Abidin NE, Dahalan, NH. (2016) Fresh Properties and Flexural Strength of Self-Compacting Concrete Integrating Coal Bottom Ash, MATEC Web Conf., 47:01010. https://doi.org/10.1051/matecconf/20164701010

[20] Ramadhansyah PJ, Abu Bakar BH, Megat Azmi MJ, Wan Ibrahim MH (2011) Engineering properties of normal concrete grade 40 containing Rice husk ash at different grinding times, Int. J. Technol., 2(1):10-19.

[21] Mangi SA, Wan Ibrahim MH, Jamaluddin N, Shahidan S, Arshad MF, Memon SA, Ramadhansyah PJ, Mudjanarko SW, Setiawan MI. (2019) Influence of Ground Coal Bottom Ash on the Properties of Concrete, Int. J. Sustain. Constr. Eng. Technol., 9(2):26-34. https://publisher.uthm.edu.my/ojs/index.php/IJSCET/article/view/3296 